\title{
Гендерная элитология
}

Как правило, гендерные проблемы сводятся к решению вопроса: имеют ли женщины право носить гордое звание «человек» или это доступно только представителям мужского пола. Говоря о гендерной элитологии не будем сводить всю ее проблематику к обоснованию постулата о том, что женщины могут занимать руководящие посты и управлять не хуже мужчин семьей или страной. Примем равенство возможностей среди полов за данность. Предмет гендерной элитологии намного шире. В самом общем приближении хотелось бы сформулировать основные вопросы гендерной элитологии - каков половой состав элит в зависимости от их вида и типа (исходя из многочисленных теорий по типологии элит), каковы половые особенности рекрутирования в элиту (так для женщины более доступен, чем для мужчин, такой путь попадания в элиту, как вступление в брак с представителем привилегированных слоев общества), место женщин в элите на разных исторических этапах и т.д.

Не смотря на принятое нами за данность равенство возможности полов, нельзя не отметить, что на первый взгляд на протяжении всей истории человечества (за исключением такого спорного факта как существование матриархата на первобытном этапе развития общества) во всех видах и типах элит преобладали представители мужского пола. Не будем связывать это исключительно со злонамеренным желанием мужчин не пускать женщин на руководящие посты и к управлению крупными капиталами. Неизменным остается тот факт, что вынашивает и вскармливает (несмотря на то что с развитием искусственного питания этот процесс может обойтись без участи женщины) ребенка по-прежнему женщина. Воспитывает маленьких детей также в основном женщина, а репродуктивный цикл отнимает у женщины время и 
силы, которые мужчина использует в других сферах жизни, обгоняя женщину. И поэтому, как правило, женщина обгоняет мужчину тогда, когда она не замужем, не рожала, не воспитывает ребенка или детей. Фундаментальное различие в ролях мужчины и женщины, появившееся в филогенезе, не может не продолжаться в онтогенезе.

Но вот в чем вопрос - у всех мужчин представителей самых разных элит есть матери, жены и дочери, какую роль играют они при высокопоставленном, богатом, известном и т.д. и т.п. муже, сыне, отце? Насколько часто выполняют роль «серого кардинала», или активно способствуют элитному положению своего мужчины? Женщины при выдающихся мужчинах - один из излюбленных сюжетов писателей и кинематографистов, в их отношениях, как правило, всегда есть интрига и лихо закрученный сюжет. Но сегодня для нас научный интерес предоставляют не отдельные личности, а элита как социальный слой, живущий по своим законам.

Современное общество экономически развитых стран - это общество среднего класса, который составляет порядка $85 \%$ от всего населения. Говоря о гендерных проблемах ученые - экономисты, социологи и психологи, как правило, обращаются именно к данному слою общества. Нам бы хотелось отметить тот факт, что гендерные проблемы элиты, особенно в области экономических взаимоотношений будут сильно отличаться от аналогичных проблем, среднего класса.

Исследователи занимающиеся гендерными проблемами управления ${ }^{1}$ отмечают, что для России сегодня характерно исключительно низкое представительство женщин на уровне принятия решений как в государственном, так и в негосударственном секторах занятости. Среди высших государственных служащих женщины составляют всего 5,7\%, тогда как в категории старших служащих их насчитывается практически половина - 49,9\%, а в категории

\footnotetext{
${ }^{1}$ Тюрина И.О. Гендерные аспекты занятости и управления, М.: 2002.
} 
младших - свыше 80\%. Аналогичным образом выглядит гендерная «пирамида власти» и в негосударственном секторе: в 1995 г. среди владельцев и управляющих 125 крупных московских компаний было всего лишь две женщины, а среди 138 представителей бизнес-элиты -только 11 женщин (8\%)². В целом тенденции в сфере должностной структуры занятости женщин таковы: чем выше должностная ступень, тем ниже доля женщин в общем числе занятых на ней.

Для описания подобных явлений часто используется термин «стеклянный потолок» ${ }^{3}$, введенный в научный оборот вначале 1980-х гг. Данное явление подразумевает, что, несмотря на формально равные возможности для обоих полов, существует множество неформальных, «невидимых» барьеров, препятствующих продвижению женщин по ступеням должностной иерархии. Сегодня природа и характер «стеклянного потолка» изменились: в большинстве случаев современные женщины, хотя и не устраняются открыто от занятия руководящих должностей, получают в компаниях посты, имеющие лишь видимость власти и престижа. Так, американские исследователи используют указанный термин для описания ситуации, складывающейся в юридических фирмах, академической медицине, а также в крупных корпорациях, где продвижение женщин на высшие ступени управленческой структуры тормозится методами скрытой дискриминации.

В силу вышеперечисленных причин (репродуктивный период женщины не позволяющий ей активно заниматься карьерой) продолжает сохранять тенденция когда современные мужчины имеют гораздо больше возможностей выстроить свою трудовую карьеру, чем женщины, у которых она (карьера) попрежнему определяется вынужденными факторами, в том числе не связанными напрямую со структурой рынка труда. И, тем не менее, женщины продолжают

\footnotetext{
2 Римашевская Н. Гендерные аспекты социально-экономической трансформации в России // Социальные последствия рыночных реформ в России. М., 1997, с.150.

3 Учет гендерных факторов в процессе принятия экономических решений // Хроника ООН, ноябрь 1995. Т. XXXVI. № 2, c. 228.
} 
наступать в сфере занятости, к тому же подчас в самых интеллектуальных и престижных ее секторах и, прежде всего, в управлении и предпринимательстве. По наблюдениям западных специалистов ${ }^{4}$, особенно активным это наступление стало в последние 20 лет. В качестве доказательства они упоминают США, где численность работающих женщин составляла к 1990-м годам 51\% занятых, в то время как в недалеком прошлом она не превышала 30-40\%. Но опять же эта тенденция охватывает представителей среднего класса, среди женщин предпринимательниц большую долю даже в США составляют владелицы мелкого бизнеса.

Вместе с тем, за пределами США женщинам принадлежит всего $1 \%$ руководящих должностей в 1000 крупнейших корпорациях ${ }^{5}$. Так, в Англии женщины, хотя и составляют $40 \%$ занятых, занимают лишь $10 \%$ постов менеджеров ${ }^{6}$. Несмотря на активное вхождение женщин в управленческую деятельность в области экономики, среди них пока невелико число менеджеров не только высшего, но даже и среднего уровня.

Некоторые страны пытаются уравновесить гендерное представительство путем законодательной деятельности. Так в Норвегии в 2003 г. вышел закон согласно которому в руководстве компаний, чьи акции торгуются на бирже, должно быть не менее 40\% представителей слабого пола. Пять лет назад в советах директоров крупных компаний было всего 7\% женщин. Закон вступал в силу постепенно и распространился на всех эмитентов лишь в 2006 году, при этом компаниям давалось еще два года на осуществление необходимых преобразований. Сегодня средняя доля женщин в советах директоров норвежских компаний $-42 \%$.

Соотношение представителей мужчин и женщин в отраслевых элитах

\footnotetext{
${ }^{4}$ Rossman M. Breaking down barriers: Nine stories // Rossman M. The international businesswoman of the 1990s. A guide to success in the global market-place. Women in business: A world of opportunity. N.Y. etc., 1990, c.1-11.

5 Учет гендерных факторов в процессе принятия экономических решений // Хроника ООН, ноябрь 1995. XXXVI. № 2, c. 45.

${ }^{6}$ Женщины в бизнесе. М.: ИНИОН РАН, 1993, с. 62.
} 
достаточно разнообразное. По данным ЮНЕСКО, в науке доминируют мужчины. Лишь четверть ученых - женщины, среди профессоров всего $10 \%$ женщин, среди академиков - 5\%. Из 806 нобелевских лауреатов всего 41 женщина. Подавляющее большинство ректоров Вузов - мужчины. Тогда как в среднем образовании ситуация прямо противоположная - 85\% директоров школ женщины.

В России гендерные проблемы высших слоев общества отличаются так же как и всё социально - экономическое развитие. В Советском Союзе была специальная квота на присутствие женщин в органах власти: в период строительства социализма в партийных документах был провозглашен курс на равноправное участие женщин и мужчин в управлении, в том числе и производством.

Российская специфика состоит в том, что женщины и мужчины начали заниматься бизнесом одновременно. С началом перестройки у нас были компетентные руководители - как мужчины, так и женщины, имевшие опыт управленческой деятельности, одинаково высокий уровень образования и, главное, образцы для подражания: руководителей своего пола. Поэтому у мужчин и женщин оказались во многом равные стартовые позиции, и тот факт, что женщины активно занимаются управлением, никого не удивляет.

Российские социологических исследований, показывают наметившийся рост доли женщин-предпринимателей в общей численности предпринимательского слоя ${ }^{7}$. По данным исследования 1996 г., женщины составили одну пятую часть слоя собственников предприятий и фирм, а также лиц, профессионально занятых бизнесом. Так же как и в других странах, как правило, женщинам принадлежат мелкие предприятия, $20 \%$ женщинпредпринимательниц заняты производственным бизнесом. $40 \%$ женщин принявших участие в исследовании могут быть отнесены к категории

7 Силласте Г.Г. Социально-психологический облик россиянок. Доклад на 3 Международной Гендерной Конференции "Мужчина и женщина: меняющиеся роли и образы". 14-16 октября 1997. М., 1997. 
«полупредпринимателей», сочетающих собственное дело с работой по найму. Вместе с тем, проникновение женщин в крупный российский бизнес не носит пока массового характера: несмотря на позитивные тенденции, женское предпринимательство продолжает испытывать определенные трудности, часть которых связана с социально-экономическими факторами, а часть - с феноменом культурной инерции, сохраняющей патриархальные стереотипы ${ }^{8}$. По мнению А. Чириковой, становление женского предпринимательства в России можно назвать процессом, который формируется «снизу»: государство декларирует, но не помогает «слабому полу».

Если говорить о бизнес-элите, то по данным журнала Forbes, за все время составления российской «золотой сотни» самых богатых людей нашей страны с заведомым упорством там присутствует только одна женщина - Елена Батурина, владелица фирмы «Интеко», жена мэра г. Москвы Ю.М. Лужкова. Помимо того, что Е.Батурина входит в «золотую сотню» она вошла в тройку богатейших женщин мира по версии Forbes. Опередить в рейтинге супругу московского мэра Юрия Лужкова удалось лишь китаянке Ву Яхун (состояние - \$3,9 млрд), возглавляющей Longfor Properties, и испанке Розалии Мера (\$3,5 млрд), одной из основательниц торговой империи Zara.

Половину списка богатейших женщин планеты составили представительницы Азии, преимущественно, гражданки КНР. При этом лишь одна женщина из рейтинга пытается конвертировать свои бизнес-успехи в политические дивиденды: американка Мег Уайтмен является кандидатом от Республиканской партии на пост губернатора Калифорнии, составляя конкуренцию нынешнему главе штата Арнольду Шварценеггеру. По некоторым данным, на избирательную кампанию 54-летняя предпринимательница потратила уже $\$ 70$ млн. из своего состояния в $\$ 1,3$ млрд.

\footnotetext{
${ }^{8}$ Чирикова А.Е. Женщина во главе фирмы. М.: Изд-во Института социологии РАН, 1998, с. 28.
} 
Еще одним интересным фактом «женского» рейтинга Forbes является семейный характер бизнеса многих его представительниц. По меньшей мере пять богатейших женщин мира начинали свое дело совместно с мужьями или братьями.

Если говорить о психологии менеджмента, то специалисты в этой области (Дж. Виткин, С. Картер, М. Хеннинг, А. Жарден) отмечают следующие причины, препятствующие женщине достигать успехов в лидерстве: женщины в среднем гораздо позже мужчин начинают заботиться о личной карьере, являются ярко выраженными носителями исполнительской психологии и как таковые утрачивают инициативность, независимость, решительность и самостоятельность; они более эмоциональны и хуже умеют управлять собой; женщины менее склонны к риску: сомнения и боязнь заставляют их перестраховываться и откладывать не терпящие отлагательства решения; они чаще прибегают к так называемым «комбинированным стратегиям» жизненного пути, при которых работе отводится столь же существенная роль, как и семье и т.п. ${ }^{9}$.

Хотф указанные трудности приводят к тому, что возникает установка связанная с признанием меньших возможностей женщин как лидеров организаций по сравнению с мужчинами, опыт развития женского предпринимательства и реальная практика повседневной жизни демонстрируют обратное. Женщины, занявшие лидерские позиции, как правило, справляются с этим бременем и не уступают мужчинам. Таким образом, социальнопсихологические ограничения для вхождения женщин в бизнес не могут быть отнесены к «неизменяемым факторам»: эффективные модели делового поведения могут формироваться непосредственно в ходе реализации поставленных задач. Дж. Розенер (Школа менеджеров при Университете штата Калифорния) исследовала особенности стиля женского управления фирмой и

\footnotetext{
${ }^{9}$ Чирикова А.Е. Женщина во главе фирмы. М.: Изд-во Института социологии РАН, 1998, с. 37-41.
} 
пришла к выводу, что, если первые женщины-управляющие принимали правила поведения, характерные для мужчин, и это приводило их к успеху, то женщиныруководительницы второй волны достигали успеха, создавая и разрабатывая свой «специфически женский» стиль управления ${ }^{10}$.

Гендерная элитология как объект научного интереса сегодня является весьма перспективной, позволяя посмотреть на проблемы элиты общества с новой весьма интересной точки зрения.

${ }^{10}$ Бабаева Л.В. Женщины России в условиях социального перелома: работа, политика, повседневная жизнь // Российский общественный научный фонд. Научные доклады 34. М., 1996, с. 74-85. 
Список литературы:

1. Бабаева Л.В. Женщины России в условиях социального перелома: работа, политика, повседневная жизнь // Российский общественный научный фонд. Научные доклады 34. М., 1996.

2. Женщины в бизнесе. М.: ИНИОН РАН, 1993.

3. Римашевская Н. Гендерные аспекты социально-экономической трансформации в России // Социальные последствия рыночных реформ в России. М., 1997.

4. Силласте Г.Г. Социально-психологический облик россиянок. Доклад на 3 Международной Гендерной Конференции "Мужчина и женщина: меняющиеся роли и образы". 14-16 октября 1997. М., 1997.

5. Тюрина И.О. Гендерные аспекты занятости и управления, М.: 2002.

6. Учет гендерных факторов в процессе принятия экономических решений // Хроника ООН, ноябрь 1995. Т. ХXXVI. № 2.

7. Чирикова А.Е. Женщина во главе фирмы. М.: Изд-во Института социологии PAH, 1998.

8. Rossman M. Breaking down barriers: Nine stories // Rossman M. The international businesswoman of the 1990s. A guide to success in the global market-place. Women in business: A world of opportunity. N.Y. etc., 1990. 